\title{
Roger Cook Responds
}

To the Editor:

In his comments on my theory, V. Krishnan addressed issues that lie at the point where transcendental and scientific perspectives of the near-death experience (NDE) converge. The main thrust of his letter, that reincarnation involves processes that are purely physical and therefore amenable to empirical investigation, highlights a dichotomy at the center of near-death studies. On the one hand is the transcendental viewpoint adopted by the mystic, and on the other the neurobiological model propounded by neuroscientists (Saavedra-Aguilar and Gómez Jeria, 1989).

In an earlier letter, Krishnan (1989) furnished two examples of how the transcendental approach to NDEs may complement rather than compete with the neurobiological approach. Krishnan drew attention 
to the Hindu tradition about the notion of time, which results from our awareness that events in life are successive, following one after the other. This concept of time reflects a basic biological drive; in order to survive, the human organism must absorb sustenance at periodic intervals. It is this recurring need that gives rise to humankind's perception of time as sequential, the "And then ..., and then ..." perspective I adumbrated in my article (Cook, 1989).

Krishnan went on to describe how the practitioner of yoga, in achieving the ultimate state of contemplation, samaadhi, or "pure being," succeeds in neutralizing this biological imperative. Instead, time stands still for the yogi, who commonly reports a quality of radiance, as of "a thousand suns." It seems reasonable to infer, as Krishnan did, that the radiant light experienced by the practitioner in this state is similar to that experienced in an NDE. However, it is also possible to infer that the mechanism that gives rise to this phenomenon can be explained neurophysiologically.

One such explanation was suggested by Susan Blackmore and Tom Troscianko (1989). During the process of death the cerebral cortex is starved of oxygen, which causes inhibitory neurons to be suppressed, with a consequent state of hyperactivity. The cells in the visual cortex will start firing randomly, but because they are denser at the center, the result will be a flickering speckled world that gets brighter and brighter farther from the center. The light is perceived as extremely bright, but does not hurt the eyes, because the eyes are not involved at all.

This would be undeniably real to the experiencer. It would at the same time, equally undeniably, be intracranial and therefore not perceivable by an observer. In due time, the yoga practitioner would withdraw from the state of samaadhi and the NDEr would be resuscitated. Both would report an experience that was vivid, real, and true for them.

To return to Krishnan's current letter, my assertion that nothing leaves the body has a dogmatic ring, but I intended to imply no more than that I am aware of no evidence that meets my standards of verifiability for something leaving the body. It may be that impressions of a personality can survive in a physical locale, as Ian Stevenson's work (1987) suggests, and I have some sympathy for the findings of Janusz Slawinski (1987) and of Cyril Smith and Simon Best (1989), insofar as I have been personally convinced by demonstration that water-divining or dowsing does genuinely work. I am particularly in sympathy with the final phrase of Krishnan's letter: my dream and his mystical experience (Krishnan, 1989) can be evidential only for each of us as individuals. 
As Ernst Rodin cautioned (1989, p. 258): "Neurophysiology and neurochemistry can give isolated insights, but the demonstration of how neuronal firing patterns are transmuted into a thought or feeling is beyond our capabilities at this time." Contributions such as those of Blackmore and Troscianko signal the direction in which this kind of research needs to go. It seems to me vital that this kind of research and transcendental insights are received as mutually supportive, not mutually exclusive.

\section{References}

Blackmore, S. J., and Troscianko, T. S. (1989). The physiology of the tunnel. Journal of Near-Death Studies, 8, 15-28.

Cook, R. B. (1989). A theory of death. Journal of Near-Death Studies, 8, 5-14.

Krishnan, V. (1989). Consciousness and substance: The primal forms of God (Letter to the editor). Journal of Near-Death Studies, 8, 119-121.

Rodin, E. (1989). Comments on "A neurobiological model for near-death experiences." Journal of Near-Death Studies, 7, 255-259.

Saavedra-Aguilar, J. C. and Gómez-Jeria, J. S. (1989). A neurobiological model for neardeath experiences. Journal of Near-Death Studies, 7, 205-222.

Slawinski, J. (1987). Electromagnetic radiation and the afterlife. Journal of Near-Death Studies, 6, 79-94.

Smith, C. W., and Best, S. (1989). Electromagnetic man: Health and hazard in the electrical environment. New York, NY: St. Martin's Press.

Stevenson, I. (1987). Children who remember previous lives. Charlottesville, VA: University Press of Virginia.

Roger B. Cook The Old Farmhouse

Steeple Langford Salisbury, Wilts SP3 4LZ

United Kingdom 